\title{
The Impact of Trust on Entrepreneurship in Poland
}

\section{Marta Młokosiewicz ${ }^{1}$ and Sandra Misiak-Kwit ${ }^{2}$}

\begin{abstract}
In the global rankings of generalized trust, Poland occupies a lowly position. Only $1 / 3$ of Poles have a strong trust in strangers and roughly the same number believe that trust in business generally pays off. At the same time, only half of them believe that a market economy based on private enterprise is the best economic system for the country. According to the literature review a major factor in the development of entrepreneurship is trust in other economic actors. The aim of the article is to present the relation between trust and entrepreneurial activities in Poland. In this paper the hypothesis was adopted that the level of trust in the public sphere, especially in business relations in Poland, had an impact on the intensity of entrepreneurial activities. The analysed period comprises the years from 2002 to 2016. The article presents changes in the potential for social trust, including trust in business. Indicators of confidence include the percentage of people that have trust in different actors in Poland. A further part of the paper is devoted to the phenomenon of entrepreneurship in Poland. Among the indicators of entrepreneurship are the number of newly registered and deregistered entities, and entities that are new or deregistered from the REGON register per 10 thousand of population. Moreover, the innovation activity of enterprises in Poland has been described. At the end, relations between trust and entrepreneurial activities in Poland were examined. The data was analysed statistically with Pearson's correlation coefficients. The analysis of confidence and entrepreneurship is based mainly on the data published by the Polish Central Statistical Office and Public Opinion Research Centre.
\end{abstract}

Keywords: trust, confidence, social capital, entrepreneurship, innovativeness, Poland.

1 Marta Młokosiewicz, Ph.D., Assistant Professor, University of Szczecin, Faculty of Economics and Management, Department of Human Capital Management, ul. Mickiewicza 64, 71-101 Szczecin, Poland, e-mail: marta.mlokosiewicz@ usz.edu.pl.

2 Sandra Misiak-Kwit, Ph.D., Assistant Professor, University of Szczecin, Faculty of Economics and Management, Department of Human Capital Management, ul. Mickiewicza 64, 71-101 Szczecin, Poland, e-mail: s.misiak@wneiz.pl.

Received 12 May 2017; Revised 17 August 2017; Accepted 9 November 2017 


\section{INTRODUCTION}

In the global rankings of generalized trust Poland occupies a lowly position. Only $1 / 3$ of Poles place strong trust in strangers and roughly the same number believe that trust in business generally pays off. At the same time, only half of them believe that a market economy based on private enterprise is the best economic system for the country. According to the literature review, trust in other economic actors is a major factor in the development of entrepreneurship. Does the level of trust in Poland affect the number of entrepreneurial actions undertaken, and the number of businesses established and deregistered? Is there a relationship between the level of trust and innovative activity registered by enterprises? These questions contributed to the research on the relation between trust and entrepreneurial activities in Poland.

The objective of the article is to present the relation between trust and entrepreneurial activities in Poland. In this paper it was assumed that the level of trust existing in the public sphere, and particularly in business relations in Poland, had an impact on the intensity of undertaken entrepreneurial activities. The rest of this paper in organized into five sections. Section 2 deals with the literature review; section 3 discusses research methods; section 4 analyzes the results while section 5 discusses them. Section 6 concludes the paper. In the paper, changes in social trust potential were presented, including trust in the business sphere, for the period between 2002 and 2016. The percentage of individuals placing trust in various entities was adopted as trust indicators. A further part of the paper was dedicated to the phenomenon of entrepreneurship. This part features the data regarding the number of newly-registered and deregistered enterprises in a given year, as well as the number of entities newly-registered in and removed from the National Economy Register (the REGON register) per 10 thousand of population; innovative activity in the services and industry sectors was further described. Following that, the existence of a significant correlation between trust and manifestations of entrepreneurial activities was examined with the use of a Pearson correlation coefficient. The analysis of trust and entrepreneurship was chiefly based on figures obtained from the Chief Statistical Office (GUS) and the Centre for Public Opinion Research (CBOS).

\section{LITERATURE REVIEW}

Successful business activity and entrepreneurial activity are significantly influenced by the stable behavior of economic actors as well as by the transparency of the macro and micro business environment. These factors 
shape economic order and a sense of security, by building the institutional trust of the individuals starting their business activity and the entrepreneurs already operating in the market. Market participants are then convinced that the existing formal structures guarantee the responsible conduct of other entities, and due to possible sanctions imposed for breaking rules, they feel protected from the negative consequences of the actions of others (Pretty \& Ward, 2001). Institutional trust is grounded in legal forms; networks based on general social norms; and the rules applicable to a given sector. They may be equated with faith and an expectation that the other party will act in a predictable and universally acceptable fashion.

A high degree of social trust is beneficial to the economic sphere: it reduces transaction costs (frees up time and financial outlays) related to contract monitoring and enforcement, it facilitates co-operation and has a positive impact on enterprise innovativeness (de Clercq \& Dakhli, 2003; Kaasa, 2007; Keeley, 2007), it facilitates the co-ordination of group activities (also in the manufacturing environment), as well as the popularization and implementation of new technologies (Wallis, Killerby \& Dollery, 2004). According to the research results on the European Union countries, there is a strong positive correlation between an average level of social trust and a summary innovation index. High social trust in Denmark, Sweden, Finland, and Switzerland favors greater innovation in those countries as compared to other European states. An opposite situation, confirming the above-mentioned correlations, exists in Eastern Europe, and in particular in Bulgaria, Slovakia and Poland, as well as in Portugal, where a low degree of social trust accompanies a relatively low level of innovation (NBP, 2016).

The establishment and development of enterprises is strongly linked with the sphere of social principles. If social norms allow for dishonest conduct, which is further strengthened by informal networks of relations, and if justice cannot always be easily found within the existing legal forms, economic order is upset, and in place of institutional trust, distrust emerges. There is substantial consent to dishonesty in Poland (Młokosiewicz, 2015).

Trust in business relations - apart from the fact that it develops in an institutional context - also has its personal dimension. Personal trust is formed, on the one hand, through the prism of the history of previous interactions with business partners, and the resultant knowledge of the other party's professionalism, its honesty, reliability, and on the other hand - a person's inclination to trust arising from their personal traits, their openness to others and their ability to risk trusting an individual. Trust can be based on a calculation of profits and costs involved in starting cooperation - it is then a rational choice aimed at maximizing its usefulness based on a calculation of benefits arising from entering into a relationship. Along with a growing number 
of interactions, observation of mutual conduct and accumulated experiences, the risk of showing / not showing trust decreases, since the knowledge of the other party expands. Therefore, five dimensions play a material role in trust development: personal, calculation-based, institutional, perception-centered and knowledge-based dimensions (McKnight, Cummings \& Chervany, 1998). It must be emphasised that limitless trust has no place in business relations. Thus, trust in business rather needs to be viewed in terms of "confidence" and setting boundaries, rather than "trust" (Handy, 1995). The question of building one's own credibility becomes an issue of importance, which is not so much a task, but rather a process (Lewandowski, 2008, p. 178). As demonstrated by the results of the study titled Social capital and trust in Polish business 2015, only $38 \%$ of Polish entrepreneurs were aware of the connection between enterprise credibility and its economic condition - they admitted that undertaking actions aimed at raising enterprise credibility would increase its sales volume in the last 12 months. From the estimates presented in the aforementioned report, it arises that in 2014 the lack of enterprise credibility-boosting activities in Poland translated into losses resulting from lost contract opportunities to the tune of PLN 66.3 billion (approx. 3\% of GDP), whereas out of fear (demonstrated by as many as $52 \%$ entrepreneurs) of contractors' dishonesty, contracts worth between PLN 145 and 215 billion were not concluded (approx. 10\% of GDP). $35 \%$ of business people claimed that many transactions are not concluded, because potential business partners treat them as being anonymous and untested. On the other hand as many as $75 \%$ of the respondents admitted that "one still needs to be cautious in order to avoid being cheated" (Social Capital and Trust in Polish Business, 2015). Thus, a significant degree of distrust dominated in business relations.

The core of entrepreneurship is starting up business activity (Griffin, 1997, pp. 730-731; Targalski \& Francik, 2009, p. 21). Referring to the literature on the subject, the creation of new things and a time-consuming, work-intensive or risky process need to be recognized as fundamental entrepreneurial activity (Hisrich \& Peters, 1992, p. 6). According to the studies in the field of economics, innovativeness constitutes an inseparable part of the entrepreneurial activities undertaken. The result of an entrepreneurial process in such circumstances is the employment of possessed resources in a unique manner (Kraśnicka, 2002). In foreign literature the combination of the phenomenon of entrepreneurship with innovations has also been described for many years. According to Churchill and Lewis (1992, p. 27), an entrepreneurial process can be defined as formulating and discovering opportunities in order to create new values not only through innovation, but also through acquiring the requisite resources or managing the process of value development. In a document describing entrepreneurship in Europe (2003, pp. 5-6) the European Commission also 
indicates that entrepreneurship is not merely an attitude focused on the creation of a new value, but also on the application of innovation and creativity.

\section{RESEARCH METHODS}

While reviewing the literature an exploratory design was adopted. It was the initial stage of the research. It included data and information gathered from various books, articles, journals, and reports of both Polish and foreign publications that are relevant to the study. The secondary data was collected from the Chief Statistical Office (GUS) and the Centre for Public Opinion Research (CBOS) for the period extending from 2002-05 to 2015-16. Table 1 provides a summary of the data source and period involved. While analyzing the secondary data the descriptive design of quantitative nature has been used.

Table 1. Summary of data source and the period

\begin{tabular}{lll}
\hline Data description & Period & Sources \\
\hline Institutional trust & $2002-2016$ & GUS (2015); CBOS (2016) \\
$\begin{array}{l}\text { Trust in institutions in countries listed in } \\
\text { Edelman Trust Barometer }\end{array}$ & $2013-2016$ & Edelman Trust Barometer \\
Trust and distrust in Poland & $2002-2016$ & CBOS (2016) \\
Intensity of entrepreneurial activities & $2003-2015$ & GUS (2017) \\
Innovative activity in the industrial sector & $2005-2015$ & GUS (2017) \\
Innovative activity in the services sector & $2005-2015$ & GUS (2017) \\
\hline
\end{tabular}

In order to obtain the information on the correlation between variables (trust and entrepreneurial activities), Pearson's correlation coefficient was employed, using the data presented by CBOS and GUS. The percentage of individuals trusting various entities was assumed as trust indicators, whereas the number of enterprises per 10 thousand of population registered in the REGON register and deregistered from the REGON register was adopted as indicators of entrepreneurial conduct, furthermore, selected manifestations of innovative activity in the industry and services were taken into consideration.

\section{ANALYSIS}

\section{Trust in Poland}

A study conducted by GUS in the first half of 2015 demonstrates that $13.1 \%$ of Poles would be willing to take advantage of employment status for their own benefit in exceptional situations, and $5.1 \%$ would sometimes be willing 
to do so. Approximately $21 \%$ of the respondents believed that in exceptional situations or occasionally, unreliable or careless performance of work could be justified, while only $40 \%$ of those surveyed by GUS claimed that employing workers illicitly and handling private matters during work time at the expense of professional duties is never justified (GUS 2015). Furthermore, from the report it arises that over $28 \%$ of Poles were decidedly or rather dissatisfied with the conditions of operating a business. Only a half of those surveyed by GUS "decidedly" or "rather" trusted local authorities, a slightly lower percentage expressed trust in courts, whereas a far smaller proportion placed their trust in legislative and executive authorities - only every fourth Pole admitted to trusting the Sejm, the Senate and the Government (Table 2).

Table 2. Institutional trust in Poland between the years of 2002-2016*

\begin{tabular}{|c|c|c|c|c|c|c|c|c|}
\hline \multirow{2}{*}{ Item } & \multicolumn{8}{|l|}{ Year } \\
\hline & 2002 & 2004 & 2006 & 2008 & 2010 & 2012 & $2015 * *$ & 2016 \\
\hline $\begin{array}{l}\text { Local city / } \\
\text { municipal }\end{array}$ & 43 & 53 & 56 & 68 & 55 & 58 & 50 & 64 \\
\hline $\begin{array}{l}\text { authorities } \\
\text { Public } \\
\text { administration } \\
\text { officials }\end{array}$ & 31 & 33 & 38 & 53 & 42 & 45 & - & 50 \\
\hline Courts & 40 & 31 & 39 & 59 & 44 & 45 & 47 & 45 \\
\hline Government & 42 & 21 & 47 & 56 & 31 & 39 & 27 & 38 \\
\hline Sejm \& Senate & 28 & 21 & 30 & 39 & 21 & 29 & 25 & 30 \\
\hline Large enterprises & 27 & 35 & 32 & 42 & 35 & 35 & - & 37 \\
\hline
\end{tabular}

Notes: * percentage of responses: "I rather trust" and "I decidedly trust" given to the question: "Overall, do you trust or distrust the institutions listed?". The research was conducted in January of each year.

** for 2015, owing to the lack of CBOS's data for the period of 2003-2015, GUS's data was provided a percentage of responses "I rather trust" and "I decidedly trust".

Source: own work on the basis of: Social Trust, CBOS, Research report No 18/2016, Social values and trust in Poland in 2015, GUS 2015.

Institutional trust in Poland was also low in international rankings. According to the Edelman Trust Barometer in 2016, as many as 65\% of Poles were distrustful of institutions, while the average percentage of those trusting institutions out of all the individuals surveyed in the index of countries was $50 \%$. In recent years the percentage has remained at the same level, whereas the difference between trust in the public sphere in Poland and average trust placed in institutions in the countries included in the Edelman Trust Barometer has grown (Table 3). 
Table 3. Trust in institutions* in Poland in comparison to other countries listed in the Edelman Trust Barometer

\begin{tabular}{lllll}
\hline Years & $\mathbf{2 0 1 3}$ & $\mathbf{2 0 1 4}$ & $\mathbf{2 0 1 5}$ & $\mathbf{2 0 1 6}$ \\
Index value** & $34(48)$ & $32(47)$ & $36(46)$ & $35(50)$ \\
\hline
\end{tabular}

Notes: * percentage of individuals having trust in institutions (the government, business, media and NGO's).

** average value of the Trust Index for all the listed countries is shown in brackets.

Source: own work on the basis of: the Edelman Trust Barometer 2013-2016.

A fundamental increase in the percentage of Poles trusting others was recorded in 2008. From that year onwards, a still small proportion of approximately $1 / 4$ of CBOS's respondents were convinced that a majority of people were trustworthy, moreover, the percentage of those preferring to exercise caution in relations with others fell, though only slightly - in the years between 2012 and 2016 that figure was 3/4 of those surveyed (Table 4).

Table 4. Trust and distrust in Poland between the years of 2002-2016*

\begin{tabular}{|c|c|c|c|c|c|c|c|c|}
\hline \multirow{2}{*}{ Item } & \multicolumn{8}{|l|}{ Years } \\
\hline & 2002 & 2004 & 2006 & 2008 & 2010 & 2012 & 2014 & 2016 \\
\hline $\begin{array}{l}\text { Overall, a majority } \\
\text { of people can be } \\
\text { trusted** }\end{array}$ & 19 & 17 & 19 & 26 & 26 & 23 & 22 & 23 \\
\hline $\begin{array}{l}\text { One needs to be } \\
\text { very cautious in } \\
\text { relations with } \\
\text { others** }\end{array}$ & 79 & 81 & 79 & 72 & 72 & 74 & 75 & 74 \\
\hline $\begin{array}{l}\text { Overall, do you } \\
\text { or don't you trust } \\
\text { strangers whom } \\
\text { you encounter } \\
\text { in various } \\
\text { situations } * * *\end{array}$ & - & - & $30(3)$ & $33(4)$ & $30(4)$ & $32(2)$ & $33(2)$ & $31(1)$ \\
\hline $\begin{array}{l}\text { Overall, do you } \\
\text { trust the people } \\
\text { you work with on } \\
\text { a daily basis**** }\end{array}$ & $58(24)$ & $53(26)$ & $60(20)$ & $\begin{array}{l}64 \\
(21)\end{array}$ & $\begin{array}{l}66 \\
(18)\end{array}$ & $\begin{array}{l}67 \\
(17)\end{array}$ & $\begin{array}{l}62 \\
(20)\end{array}$ & $\begin{array}{l}63 \\
(18)\end{array}$ \\
\hline $\begin{array}{l}\text { Trusting business } \\
\text { partners usually } \\
\text { pays off** }\end{array}$ & 24 & 29 & 27 & 33 & 34 & 38 & 33 & 35 \\
\hline $\begin{array}{l}\text { Trusting business } \\
\text { partners usually } \\
\text { ends badly** }\end{array}$ & 45 & 46 & 44 & 40 & 42 & 37 & 40 & 40 \\
\hline
\end{tabular}


$* * * *$ opinions of the respondents working full- or part-time, as well as off and on; percentage of responses: "I rather trust"; responses "I decidedly trust" are given in brackets.

Source: own work on the basis of: Social trust, CBOS, Research report No 18/2016.

The first two statements in Table 4 verified the so-called generalised trust. While the next question referred to a rather more personal dimension of trust, probably that was why the greatest number of positive responses was recorded in this case - approximately $1 / 3$ of Poles claimed that they trust the strangers whom they encountered in various situations. About $60 \%$ of the individuals surveyed by CBOS, and since 2008 even more than $60 \%$ of them, "rather" trusted their colleagues, while $20 \%$ of Poles decidedly had trust in their colleagues. A far higher percentage of positive responses to that question than in the case of strangers, or "a majority of people", demonstrates the significance of the experience of mutual relations in developing trust between parties.

Trust in business relations was at a similar level as trust in strangers. In the period between the years of 2008-2016, slightly more than $1 / 3$ of people claimed that trust in business partners is generally beneficial, and when compared to the period of 2002-2006, the number of positive responses recorded grew. However, even more Poles $-40 \%$ to be exact, were of the opinion that trusting business partners typically ends badly.

\section{Entrepreneurial activities undertaken in Poland}

According to the literature review, a low level of trust, including trust in business relations, affects the conditions of enterprise operation. Analysis of data showing the willingness to undertake entrepreneurial activities, in confrontation with changes in the level of social trust can provide interesting results_regarding the relationship between these phenomena. While data on trust has been already presented, in this part of the paper the authors gathered the data indicating entrepreneurship and innovativeness in Poland. The total number of newly-registered enterprises in a given year and newlyregistered entities in the REGON register per 10 thousand of population is presented in Table 5. Examination of the data renders it evident that from 2005 the number of newly-registered enterprises was higher than during the base year (2003). Overall, the number of newly-registered enterprises in 2015 , in comparison to the base year, rose by over one hundred and six thousand. The greatest spike was observed in 2010, when the number of newly-registered entities in the REGON register per 10 thousand of population was also the greatest and it exceeded one hundred. Yet, one year later the greatest decline in new enterprise registration was recorded. 
Table 5. Intensity of entrepreneurial activities undertaken in the period between the years of 2003-2015 in Poland

\begin{tabular}{|c|c|c|c|c|}
\hline Years & $\begin{array}{l}\text { Total number of } \\
\text { newly-registered } \\
\text { enterprises }\end{array}$ & $\begin{array}{l}\text { Total number } \\
\text { of deregistered } \\
\text { enterprises }\end{array}$ & $\begin{array}{l}\text { Newly-registered } \\
\text { entities in the } \\
\text { REGON register } \\
\text { per } 10 \text { thou. } \\
\text { population }\end{array}$ & $\begin{array}{l}\text { Entities struck } \\
\text { off of the REGON } \\
\text { register per } 10 \\
\text { thou. population }\end{array}$ \\
\hline 2003 & 253519 & 144752 & 66 & 38 \\
\hline 2004 & 233520 & 194666 & 61 & 51 \\
\hline 2005 & 261507 & 214778 & 69 & 56 \\
\hline 2006 & 297302 & 271090 & 78 & 71 \\
\hline 2007 & 295033 & 242790 & 77 & 64 \\
\hline 2008 & 317954 & 244965 & 83 & 64 \\
\hline 2009 & 349656 & 357530 & 92 & 94 \\
\hline 2010 & 402005 & 237693 & 104 & 62 \\
\hline 2011 & 346087 & 383617 & 90 & 100 \\
\hline 2012 & 358367 & 252313 & 93 & 65 \\
\hline 2013 & 365487 & 269904 & 95 & 70 \\
\hline 2014 & 357351 & 304687 & 93 & 79 \\
\hline 2015 & 359973 & 292358 & 94 & 76 \\
\hline
\end{tabular}

Source: own work on the basis of GUS.

Providing that willingness to start one's own business is reflected in the number of registered entities, it can be assumed that the number of deregistered entities demonstrates a lack of willingness to own a business at a given place and time. It needs to be emphasised that the increment of deregistered businesses in 2015 in relation to the base year was greater than in the case of newly-registered companies and it amounted to over one hundred and forty seven thousand. The most intensive changes in the number of deregistered companies occurred between the years 2009-2012, while the highest indicator reflecting the number of entities struck off of the REGON register per 10 thousand of population, equaling 100, was observed in 2011. Comparing the number of newly-registered and deregistered enterprises in the examined period, it is worth noting that in the years 2009 and 2011 the number of deregistered businesses exceeded the number of those newlyregistered. Additionally, the difference between the number of new and deregistered enterprises was significantly smaller in 2015 (it amounted to over sixty seven thousand) than in 2003 (when it was over one hundred and eight thousand). These calculations lead to a conclusion that despite the increase in the number of new registrations, the spike of deregistered 
entities was greater and a disproportion between those figures narrowed down. The data can serve as confirmation of the difficult conditions for running a business in Poland.

The paper examines not only the data concerning the numbers of new and closed enterprises, but also the statistics demonstrating innovative operations of enterprises in the industrial sector (Table 6) and in the services sector (Table 7). Because the data for some previous years was unavailable, a slightly shorter research period was assumed.

Table 6. Innovative activity in Poland in the industrial sector in the period between the years of $2005-2015$ (\% enterprises)

\begin{tabular}{lllll}
\hline Years & Industry in total & $\begin{array}{l}\text { New, improved } \\
\text { products (for an } \\
\text { enterprise) }\end{array}$ & $\begin{array}{l}\text { New products } \\
\text { for the market }\end{array}$ & $\begin{array}{l}\text { New, improved } \\
\text { processes }\end{array}$ \\
\hline 2005 & 42.04 & - & - & 32.86 \\
2006 & 23.68 & 16.14 & 7.82 & 19.70 \\
2007 & 37.40 & 28.50 & 14.75 & 25.64 \\
2008 & 21.39 & 15.57 & 9.39 & 17.18 \\
2009 & 18.06 & 12.66 & 6.96 & 13.76 \\
2010 & 17.10 & 12.10 & 6.75 & 12.86 \\
2011 & 16.10 & 11.23 & 6.12 & 12.36 \\
2012 & 16.51 & 11.19 & 5.63 & 12.44 \\
2013 & 17.13 & 11.01 & 5.71 & 12.82 \\
2014 & 17.52 & 11.72 & 6.20 & 12.95 \\
2015 & 17.58 & 11.77 & 6.49 & 13.03 \\
\hline
\end{tabular}

Source: own work on the basis of GUS. Retrieved from https://bdl.stat.gov.pl/BDL/dane/podgrup/temat -08.02 .2017 .

Irrespective of the fact as to whether the analysis focuses on a percentage of businesses introducing overall innovations in the industrial sector, or separate innovations in the form of new processes or new products for the entire market, or only for a given enterprise, a distinct decline becomes evident when compared to the base year. Enterprises operating in the industrial sector in Poland were becoming less and less innovative in the examined period: in 2005 it was recorded that about $42 \%$ of enterprises implemented innovations, while in 2015 that figure was down to only $17 \%$. The most frequently implemented innovations concerned new or improved processes, while new products were far less frequently introduced to the market by companies. However, it needs to be stressed that the dynamics of change in recent years was low and, although since 2012 the percentage 
of innovation implementing enterprises has been on the rise, that rise was insignificant.

Table 7. Innovative activity in Poland in the services sector in the period between the years of $2005-2015$ (\% enterprises)

\begin{tabular}{lllll}
\hline Years & Services in total & $\begin{array}{l}\text { New, improved } \\
\text { products }\end{array}$ & $\begin{array}{l}\text { New products } \\
\text { for the market }\end{array}$ & $\begin{array}{l}\text { New, improved } \\
\text { processes }\end{array}$ \\
\hline 2005 & - & - & - & - \\
2006 & 21.22 & 13.15 & 7.22 & 17.15 \\
2007 & - & - & - & - \\
2008 & 16.12 & 10.66 & 6.51 & 12.76 \\
2009 & 13.95 & 7.99 & 4.41 & 10.70 \\
2010 & 12.79 & 7.87 & 4.27 & 9.99 \\
2011 & 11.57 & 6.35 & 3.35 & 8.97 \\
2012 & 12.38 & 7.05 & 3.43 & 9.11 \\
2013 & 11.41 & 5.81 & 2.81 & 8.50 \\
2014 & 11.41 & 6.78 & 3.95 & 8.39 \\
2015 & 9.79 & 4.82 & 2.28 & 7.39 \\
\hline
\end{tabular}

Source: own work on the basis of GUS. Retrieved from https://bdl.stat.gov.pl/BDL/dane/podgrup/temat.

In the services sector similar relations may be observed (Table 6) as in the industrial sector. The percentage of enterprises implementing innovations in services was increasingly smaller in the analysed period. It is also worth emphasising that it was lower than in the industrial sector. In 2006, 21.22\% of companies in the services sector implemented innovations, whereas in the industrial sector that figure stood at $23.68 \%$. In turn, in 2005 only $9.79 \%$ of enterprises in the services sector and $17.58 \%$ of enterprises in the industrial sector could be considered as innovative.

\section{DISCUSSION}

The objective of the article was to present the correlation between trust and entrepreneurial activities in Poland. Table 8 presents the obtained results. From Table 8 it arises that four of the analyzed relations proved to be significant. A strong negative correlation was observed between caution in relations with others, as well as the conviction that trust in business partners usually ends badly, and the number of deregistered enterprises from the REGON register. This could mean that increased caution in business relations contributed to the decreased number of deregistered entities. 
Table 8. Trust and entrepreneurship in Poland - correlations ${ }^{12}$

\begin{tabular}{lll}
\hline No. Item & $\begin{array}{l}\text { Entities newly- } \\
\text { registered in the } \\
\text { REGON register per } 10 \\
\text { thou. population }\end{array}$ & $\begin{array}{l}\text { Entities deregistered } \\
\text { from the REGON } \\
\text { register per 10 thou. } \\
\text { population }\end{array}$ \\
\hline 1. $\quad$ Overall, a majority of people & $\begin{array}{l}0.630 \\
(1.812)\end{array}$ & 0.713 \\
can be trusted & -0.726 & $-2.278)$ \\
2. In relations with others one & $-0.767^{*}$ \\
needs to be very cautious & $(-2.359)$ & $(-2.670)$ \\
3. Trust in business partners & $0.801^{*}$ & $0.845^{*}$ \\
usually pays off & $(2.987)$ & $(3.526)$ \\
4. Trust in business partners & -0.740 & $-0.782^{*}$ \\
usually ends badly & $(-2.457)$ & $(-2.807)$ \\
5. Overall, do you trust the & 0.486 & 0.709 \\
people you work with on & $(1.244)$ & $(2.248)$ \\
a daily basis & & 0.228 \\
6. Average trust in institutions3 & 0.246 & $(0,523)$ \\
\hline
\end{tabular}

Notes: $1 r$ correlation coefficient in the table is given in bold

$2 t$ coefficient in the table is given in brackets; significance at the level of $\alpha=0.05$; $t \boldsymbol{\alpha}=2.571$

3 on the basis of Table 1

* statistically significant correlation

Source: own calculations on the basis of Tables 2, 4 and 5 .

Furthermore, a strong positive correlation was observed between the number of registrations as well as the number of businesses deregistered from the REGON register and the conviction that trust in business partners usually pays off. The results might suggest that in Polish circumstances trust in business might not actually pay off, despite previous optimism in the attitude to relations with others (reflected in the correlation between trust and newlyregistered entities). The conclusions drawn from the conducted analysis further demonstrate that trust in institutions might not have a significant impact on decisions of registering and deregistering a company.

On the basis of the accumulated data, the relation between enterprise innovative activity (both industrial and service-providing enterprises - Tables 6 and 7) and institutional trust (Table 2), generalized and personal trust (Table 4) was analyzed. Only three out of the calculated correlation coefficients proved to be significant. There was a strong positive correlation between trust in the government and innovations (overall) in the industry (Pearson's $r$ correlation coefficient assumed the value of $0.819, t=3.193$ for $t \alpha=3.182$, $\alpha=0.05)$. Moreover, a strong negative correlation was found between the conviction that trust in business partners pays off and innovations (overall) in the industry (Pearson's $r$ correlation coefficient assumed the value of $0.792, t=-2.903$ for $t \alpha=2.776, \alpha=0.05$ ), as well as between the conviction 
that trust in business partners pays off and innovations concerning new and improved processes in industry (Pearson's $r$ correlation coefficient assumed the value of $-0.841, t=-3.470$ for $t \alpha=2.776, \alpha=0.05$ ).

\section{CONCLUSION}

In the paper, changes in the potential of social trust were presented, including trust in the business sphere, in the period between the years of 2002-2016, adopting the percentage of individuals placing trust in various entities as trust indicators. Subsequently, the manifestations of entrepreneurial activities in Poland were analysed, presenting the data regarding the number of newlyregistered and deregistered companies in a given year, as well as newlyregistered entities and the ones struck off of the REGON register per 10 thousand of population. Furthermore, innovative activity in the services and the industrial sector was described.

In the paper a hypothesis was adopted that trust development in the public sphere, and in particular in business relations in Poland, affected the intensity of entrepreneurial activities. The deliberations show that both institutional and personal trust, as well as positive norms and values that contribute to high levels of trust, are important to the development of entrepreneurial initiatives. The conducted analysis proved that trust in institutions was fairly low in Poland, also with reference to the European average. What is more, a low level of generalised trust was noted. On average, the trust indicator in business partners was approximately 10 percentage points higher. A significant percentage of Poles were dissatisfied with the conditions of operating a business. They demonstrated a significant degree of distrust regarding contractors' credibility and reliability, which in the context of substantial social acceptance of unethical behavior, does not surprise. Thus, it seems that the distrust persistent in the society and business relations supressed entrepreneurial activities.

From the data presented in the paper it arises that the number of newlyregistered companies has grown and Poles' willingness to set up a business is increasing. However, it needs to be stressed that simultaneously the number of companies deregistered from the REGON register rose, and that rise was greater than in the case of new registrations. On those grounds one could venture a claim that the conditions for conducting business activity in Poland were hard. The implementation of innovations in the industrial and services sectors was adopted as another indicator of entrepreneurial activities. The data showed a decline of entrepreneurial activity among Polish companies since, over the analysed years, the share of enterprises implementing innovations has been falling. On the grounds of the figures presented it can 
be concluded that enterprises in the industrial sector were more innovative than the ones in the services sector.

Pearson's correlation coefficient was applied in order to confirm or reject the hypothesis regarding the correlation between trust and intensity of entrepreneurial activities. The obtained results did not allow us to confirm unequivocally the adopted research hypothesis. Not all analysed correlations proved to be statistically significant. Such confirmation was only possible with regard to the relation between trust placed in the government and innovation in the industry. In the remaining cases, the observed significant correlations confirmed a universal conviction in Poland that in business relations "one can never be too cautious". It seems that in order to reverse that tendency, a change of norms and values presently persisting in the social mind would be crucial, including drawing the attention of the market agents to the need for procedural, and not task-based, development of one's own credibility. Lack of trust in business to some extent results from the negative experiences of interactions with other entities. However, due to the fact that coexistence of the discussed phenomena (trust - entrepreneurship, trust - innovativeness), might have its source in a number of other factors such as legal, market, demographic, economic, cultural, and so forth, the examined relations require further in-depth analyses, taking into consideration larger data sets. The results obtained in the paper should not be treated as strong conclusions, but rather as a contribution to further research on the verification of a hypothesis which assumes that the level of trust existing in the public sphere had an impact on innovativeness and the intensity of undertaken entrepreneurial activities. Such research would allow us to get more detailed responses to the questions posed in the paper's introduction. It would also be interesting to get answers to the following questions:

- Is a high level of trust in Poland necessary for the intensification of entrepreneurial or innovative activities?

- What is the role of social trust against the background of the other factors determining innovativeness and entrepreneurship?

- Can trust be regarded as an indirect indicator (mediator) that shapes itself against the background of the other determinants of entrepreneurship and innovativeness? Does trust strengthen their impact?

\section{References}

Audretsch, D.B. (2003). Entrepreneurship: A Survey of the Literature. Prepared for the European Commission, Enterprise Directorate General, Institute for Development Studies. London: Indiana and Centre for Economic Policy Research. 
CBOS. (2016). Zaufanie Społeczne. Komunikat z Badań nr 18. Warszawa: CBOS.

Churchill, N.C., \& Lewis, V.L. (1992). The five stages of small business growth. In W.A. Sahlman, \& H.H. Stevenson (Eds.), The Entrepreneurial Venture. Boston: Harvard Business School Publications.

Commission of the European Communities. (2003). Green Paper, Entrepreneurship in Europe. Brussels.

de Clercq, D. \& M. Dakhli (2003), Human capital, social capital, and innovation: A multi-country study. Vlerick Leuven Gent Working Paper Series 2003/18. Gent: Vlerick Leuven Gent Management School.

Edelman Trust Barometer. (GUS).

Główny Urząd Statystyczny, Bank Danych Lokalnych. Retrieved from https:// bdl.stat.gov.pl/BDL

Griffin, R.W. (1997). Podstawy Zarzq̨dzania Organizacjami. Warszawa: PWN.

Handy, Ch. (1995). Trust and the virtual organization. Harvard Business Review, May-June, 40-50.

McKnight, D., Cummings, L.L., \& Chervany, N.L. (1998). Trust formation in new organizational relationship. Academy of Management Review, 23(3), 473-490.

Hisrich, R.D., \& Peters, M.P. (1992). Entrepreneurship. Boston: Irvin.

GUS, (2015). Wartości i zaufanie społeczne w Polsce w 2015 r. Warszawa: GUS.

Kaasa, A. (2007). Effects of different dimensions of social capital on innovation: Evidence from Europe at the regional level. Faculty of Economics and Business Administration Working Paper 69. Tartu: University of Tartu.

Kapitał społeczny i zaufanie w polskim biznesie. Skrót raportu. (2015). Krajowy Rejestr Długów i Rzetelna Firma.

Keeley, B. (2007). Human capital: How what you know shapes your life, OECD Insights. Paris: OECD Publishing.

Kraśnicka, T. (2002). Przedsiębiorczość jako podmiot badań ekonomistów. Ekonomia, 4, 187-200.

Lewandowski, E. (2008). Charakter Narodowy Polaków i Innych. Warszawa: Muza.

Misiak, S. (2014). Innowacje wprowadzane przez samozatrudnione kobiety w Polsce - studium przypadków. Zeszyty Naukowe Małopolskiej Wyższej Szkoły Ekonomicznej w Tarnowie, 1(24), 149-158.

Misiak-Kwit, S. (Ed.) (2015). Entrepreneurship and human capital in theory and practice. Chosen aspects. Gospodarowanie Kapitałem Ludzkim. Zeszyt 7. Szczecin: volumina.pl.

Młokosiewicz, M. (2015). Społeczna percepcja przedsiębiorczości w Polsce w kontekście etycznym. In K. Włodarczyk (Ed.), Kapitał ludzki w gospodarce i organizacji. Wybrane problemy. Seria Gospodarowanie kapitałem ludzkim, 25-43. Zeszyt 8. Szczecin: volumina.pl.

Młokosiewicz, M. (2016). Zaufanie jako kompetencja osobista w miejscu pracy. Marketing i Rynek, 3, 640-649. 
NBP. (2016). Potencjał Innowacyjny Gospodarki: uwarunkowania, determinanty, perspektywy. Warszawa: NBP.

Pech, R., \& Cameron, A. (2006). An entrepreneurial decision process model describing opportunity recognition. European Journal of Innovation Management, 9(1), 61-78.

Pretty, J., \& Ward H. (2001). Social Capital and the Environment. World Development, 29(2), 209-227.

Targalski, J., \& Francik, A. (2009). Przedsiębiorczość i Zarzq̨dzanie Firmq. Teoria i Praktyka. Warszawa: Wydawnictwo C. H. Beck.

Wallis, J., Killerby, P., \& Dollery, B. (2004). Social Economics and Social Capital. International Journal of Social Economics, 31(3), 239-258.

\begin{abstract}
Polish)
W światowych rankingach uogólnionego zaufania Polska sytuuje się na dalszych pozycjach. Jedynie 1/3 Polaków ma zdecydowane zaufanie do nieznajomych i mniej więcej tyle samo sqqdzi, że zaufanie w interesach na ogół się opłaca. Jednocześnie tylko połowa z nich uważa, że gospodarka rynkowa oparta na prywatnej przedsiębiorczości jest najlepszym dla kraju systemem gospodarczym. W literaturze dotyczq̨cej przedsiębiorczości wskazuje się zaś, że istotnym czynnikiem jej rozwoju jest zaufanie do innych uczestników życia gospodarczego. Celem artykułu jest ukazanie relacji między zaufaniem a działaniami przedsiębiorczymi w Polsce. $W$ niniejszym opracowaniu założono, że kształtowanie się zaufania $w$ sferze publicznej, a zwłaszcza $w$ relacjach biznesowych w Polsce miało wpływ na intensywność działań przedsiębiorczych. Za okres badawczy przyjęto lata 2002-2016. W artykule ukazano zmiany $w$ potencjale zaufania społecznego, $w$ tym zaufania $w$ biznesie. Za wskaźniki zaufania przyjęto odsetek osób ufajq̨cych różnym podmiotom w Polsce. Dalszq część artykułu poświęcono zjawisku przedsiębiorczości. W tej części ukazano dane dotyczqce liczby przedsiębiorstw nowozarejestrowanych oraz wyrejestrowanych w danym roku, a także jednostek nowozarejestrowanych oraz wykreślonych z REGON na 10 tysięcy ludności; opisano również działalność innowacyjnq w sektorze usług oraz przemysłowym. Następnie zbadano, czy istniał istotny zwiq̨zek między zaufaniem a przejawami działań przedsiębiorczych posługujqc się współczynnikiem korelacji liniowej Pearsona. W analizie zaufania i przedsiębiorczości oparto się głównie na danych GUS oraz CBOS.
\end{abstract}

Keywords: zaufanie, kapitał społeczny, przedsiębiorczość, innowacyjność, Polska.

\title{
Biographical notes
}

Marta Młokosiewicz, Ph.D., is an Assistant Professor at the Department of Human Capital Management of the Faculty of Economics and Management of the University of Szczecin. She holds a PhD in Economics from the University of Szczecin. The domain of her scientific research activity comprises social capital (particularly enterprise social capital, organizational trust, trust management) and also ethics in management and corporate social responsibility. She is an 
author of several dozen publications in scientific journals and monographs. She has actively participated (also as a member of organizing committees) in numerous national and international conferences and scientific workshops.

Sandra Misiak-Kwit, Ph.D., is an Assistant Professor at the University of Szczecin - Department of Human Capital Management. Her main research areas include entrepreneurship, self-employment of women, human resources management, business ethics, communication, and business relations. She holds a PhD in Management from the University of Szczecin. She is an author of several dozen publications. She has conducted classes at such universities as: Ningbo University and Guangdong University of Foreign Studies in China, Kelaniya University in Sri Lanka, Caucasus University in Georgia, Pamukkale University in Turkey, National Academy of Science of Ukraine and University of Food Technologies in Ukraine. 
